\title{
$11: 696120-717727$
}

National Cancer Institute

\section{Source}

National Cancer Institute. 11:696120-717727. NCI Thesaurus. Code C42200.

Physical location of EPS8L2_Gene 